\title{
Crustal anatexis forms continental crust in the Izu rear-arc
}

H. Duan ${ }^{1 *}$, A.K. Barker ${ }^{1,2}$, H. Jeon ${ }^{3}$, M. Whitehouse ${ }^{3}$, C. Zhang ${ }^{4,5}$

${ }^{1}$ Department of Earth Science, Uppsala University, Sweden. ${ }^{2}$ Centre of Natural Hazards and Disaster Sciences, Sweden. ${ }^{3}$ Swedish Museum of Natural History, Stockholm, Sweden. ${ }^{4}$ Institute of Mineralogy, Leibniz University Hannover. ${ }^{5}$ Department of Geology, Northwest University, Xi'an, China. *correspondence: haochen.duan@geo.uu.se

The growth of modern continental crust is closely related to convergent plate boundaries. For continental arcs that have well-developed thick continental crust, crustal anatexis is widely accepted as origin for the voluminous silicic magmas [1]. However, oceanic arcs do not have such a thick crust [2]. The Izu oceanic arc is an ideal location to conduct a study of felsic magma evolution owing to the absence of pre-existing continental crust [3]. Here we present Boron isotope compositions of plagioclase hosted melt inclusions to investigate continental crust growth in the Izu rear-arc. The Izu rear-arc was explored by the International Ocean Discovery Program at Site U1437. The current Izu arc has formed in the last $17 \mathrm{Ma}$ and we present compositions for samples erupted between 4.3 and $7.5 \mathrm{Ma}$.

The volcanic rocks have melt inclusions with $\mathrm{SiO}_{2}$ of 63 to 72 wt.\%, classifying as dacite to rhyolite. The major element compositions of the magmas have I-type characteristics. The ranges of $\mathrm{FeOt}$ and $\mathrm{MgO}$ are from 2 to 5 wt.\% and from 0.3 to $0.9 \mathrm{wt} . \%$ respectively. The data indicate that the Izu rear-arc magmas are tholeiitic. The melt inclusions have a wide range in $\delta^{11} \mathrm{~B}$ from -3 to $+17 \%$ whereas Boron concentrations are limited between 7 and 33 ppm.

The heavy Boron isotope values $\left(\delta^{11} \mathrm{~B} \leq+13 \%\right)$ in the Izu rear-arc are not consistent with a contribution from subduction zone fluids that decrease across-arc [4]. We suggest that the Izu rear-arc felsic rocks were formed by remelting of previous mantle-derived volcanic rocks. The volcanic rocks from the Izu rear-arc with these signatures were erupted between 4.3 and $7.5 \mathrm{Ma}$. Therefore crustal anatexis is associated with almost half the history of Izu reararc volcanism. This suggests that crustal anatexis is an important mechanism for creating continental crust in the Izu rear-arc.

References:

[1] Lee et al. (2006). Contrib. Mineral. Petr., 151(2), 222-242.

[2] Hagen-Peter \& Cottle (2017). Gondwana Res., 55, 153166. [3] Bryant et al. (2003). G3 4(11), 1094. [4] Ishikawa \& Nakamura (1994). Nature 370, 205. 